e-Journal Al-Syakhsiyyah: Journal of Law \& Family Studies, Vol. 2 No.1 (2020)

(C) Fakultas Syariah IAIN Ponorogo (2020)

Published Online ; Juni 2020

\title{
STRATEGI DAN ADVOKASI PONDOK PESANTREN DALAM MENYELESAIKAN MASALAH KONFLIK SOSIAL (Studi Analisis Pondok Pesantren Al-Ittihad Jabung Lampung Timur)
}

\section{Tedi Hilmawan}

Mahasiswa Pascasarjana Fakultas Ilmu Sosial Ilmu Politik

Universitas Lampung

\begin{abstract}
ABSTRAK : Konflik sosial dengan melibatkan tindak kekerasan masa masih sering terjadi Lampung, Salah satunya di Jabung, Lampung Timur. Secara umum, konflik disebabkan karena persoalan politik, ekonomi, sosial budaya antar umat beragama, suku etnis, masyarakat dengan pelaku usaha dan distribusi sumber daya alam yang tidak seimbang. Pondok Pesantren sebagai bagian dari gerakan Civil Society selain melaksanakan institusi pendidikan, pada dasarnya dapat memberikan kontribusi besar dalam upaya menjaga keharmonisan simpul sosial kemasyarakatan dalam upaya mecegah konflik sosial. Penelitian ini bertujuan untuk menjelaskan bagaimana Strategi dan Advokasi Pondok Pesantren Al-Ittihad dalam Menyelesaikan Masalah Konflik Sosial di Jabung? Bagaimana relasi dalam penyelesaian konflik?. Metode penelitian yang digunakan adalah deskriptif kualitatif. Teknik pengambilan data melalui wawancara dan dokumentasi. Dalam implementasinya strategi dan advokasi yang dilakukan Pondok Pesantren Al-Ittihad adalah strategi persuasi dan edukasi. Strategi persuasi dilakukan dengan melakukan rapat, lokakarya, koalisi, lobi, media, dan demo. Upaya perdamaian yang dilakukan adalah menggelar dialog publik bekerjasama HPJ (Himpunan Pemuda Jabung) dan Gerakan Pemuda Ansor melibatkan pemerintah dan tokoh masyarakat. Selanjutnya, Strategi Edukasi Pondok pesantren dilakukan dengan kegiatan pengajian seperti solawat (Masbroan), istigotsah dan thoriqoh. Dalam upaya penyelesaian konflik, Pondok pesantren lebih dominan bertindak langsung ke masyarakat.
\end{abstract}

Kata Kunci : Advokasi, Pondok Pesantren, Konflik Sosial.

\begin{abstract}
The social conflicts involving mass violence often occur in Lampung, one of which is in Jabung, East Lampung. In general, conflicts are caused by political, economic, socio-cultural issues between religious communities, ethnic groups, communities and businesses and the unequal distribution of natural resources. Pondok Pesantren (The Islamic Boarding School) as part of the Civil Society movement in addition to implementing educational institutions, basically can make a major contribution in efforts to maintain harmony in the social node in efforts to prevent social conflict. This study aims to explain how the Strategy and Advocacy of Al-Ittihad Pondok Pesantren (The Islamic Boarding Schools)in Resolving Social Conflict Problems in Jabung? How are the relations in conflict resolution? The research method used is descriptive qualitative. The data collection techniques through interviews and documentation. In implementing the strategy and advocacy
\end{abstract}




\section{STRATEGI DAN ADVOKASI PONDOK PESANTREN}

\section{DALAM MENYELESAIKAN MASALAH KONFLIK SOSIAL}

carried out by the Al-Ittihad Islamic Boarding School is a persuasion and education strategy. The persuasion strategy is carried out by holding meetings, workshops, coalitions, lobbying, media, and demonstrations. Peace efforts undertaken are holding public dialogues in collaboration with HPJ (Jabung Youth Association) and Ansor Youth Movement involving the government and community leaders. Furthermore, the Education Strategy of Islamic Boarding Schools is carried out with recitation activities such as solawat (Masbroan), istigotsah and thoriqoh. In an effort to resolve conflicts, Islamic boarding schools are more dominant in acting directly to the community.

Keyword: Advocacy, Islamic Boarding School, Social Conflict.

\section{PENDAHULUAN}

Lampung merupakan salah satu Provinsi di Indonesia yang memiliki keragaman etnik, bahasa agama dan budaya. Penduduk Provinsi Lampung menurut data statistik Tahun 2015 sebesar 8.117.268 jiwa yang tersebar kedalam 15 Kabupaten/Kota. Kabupaten Lampung Tmur berada pada posisi kedua terbanyak dengan jumlah penduduk 1.008.7971. Beberapa etnik besar yang ada di wilayah ini adalah Lampung, Jawa, Sunda, Semendo, Padang/Minang dan suku dari bangsa lain yang tidak terlalu sinifikan jumlahnya².

Keragaman etnis yang ada di Lampung menunjukkan keberadaan masyarakat yang majemuk. Tidak dipungkiri, dengan kondisi masyarakat yang majemuk dampak negatifnya adalah muncul banyak konflik. Kenyataan tersebut terkonfirmasi dari hasil kajian Silviana mengenai pemetaan daerah rawan konflik di Provinsi Lampung. Dalam penelitianya dideskripsikan bahwa Akar masalah yang menyebabkan Provinsi Lampung sebagai salah satu daerah rawan konflik secara umum disebabkan karena persoalan politik, ekonomi, sosial budaya antar umat beragama, suku etnis, masyarakat dengan pelaku usaha dan distribusi sumber daya alam yang tidak seimbang ${ }^{3}$.

Riset tentang terjadinya konflik di Lampung juga pernah dilakukan oleh Iim Imadudin dengan tema Konflik, Kekerasan dan Mediasi Sosial di pedesaan Lampung. Dalam risetnya, Imadudin menjelaskan bahwa Lampung sebagai wilayah yang multietnik memiliki potensi konflik yang tinggi. Fakta sejarah menunjukkan sejumlah konflik terjadi di daerah tersebut ${ }^{4}$. Salah satu temuan dari hasil penelitianya adalah konflik yang terjadi di Desa Bungkuk Kecamatan Jabung Kabupaten Lampung Timur. Terjadinya konflik disebabkan atas dasar adanya perselisiahan antar individu yang semakin berkembang dan puncaknya terjadi aksi pembunuhan dari kedua kelompok yaitu Jawa dan Lampung. Jauh sebelum terjadinya konflik, bahwa sudah

1 Badan Pusat Statistik Provinsi Lampung, diakses pada Selasa, 08 Oktober 2019.

2 Ibid

${ }^{3}$ Leidy Silviana, "Pemetaan Daerah Rawan Konflik Di Provinsi Lampung", Jurnal Bina Praja, Vol. 05, No.03, (September 2013), 171.

${ }^{4}$ Iim Imadudin, "Konflik, Kekerasan, Dan Mediasi Sosial Di Pedesaan Lampung 1988-2001", Jurnal Penelitian Sejarah dan Budaya, Vol.1, No.1, (Maret 2009) 1-11. 
terjadi ketegangan antara kedua kelompok yaitu Jawa dan Lampung. Etnik Lampung digambarkan oleh etnik Jawa sebagai orang yang angkuh, pemalas, harga diri tinggi dan pemboros. Sedangkan etnik Jawa digambarkan sebagai orang pendatang yang tidak tau diri, rakus, penjajah dan perusak budaya Lampung.

Konflik yang terjadi di Jabung tidak hanya terjadi antar etnis. Tahun 2018 Pandu melakukan sebuah penelitian terhadap Peran Polisi Dalam Mediasi Konflik Lahan Antara Warga Dengan PT.Austasia Stockfeed Di Desa Negara Batin Kecamatan Jabung Kabupaten Lampung Timur. Konflik yang terjadi bukan antar etnis, tetapi antara warga dengan perusahaan ${ }^{5}$.

Melihat fenomena tersebut, peran pemerintah sangat diperlukan untuk meredam konflik Namun, sejauh ini upaya perdamaian yang dilakukan terhadap konflik yang terjadi ternyata belum maksimal. Jika mengutip dari gagasan Bandura terkait dengan konteks membangun perdamaian sosial, bahwa masyarakat yang hidup dalam ruang budaya sesungguhnya mengalami proses pembelajaran untuk tidak melakukan konflik atau menginginkan kedamaian ${ }^{6}$.

Selain kearifan budaya, Menurut Hamid dalam penelitianya mengenai Urgensitas Masyarakat Madani Civil Society dalam Mengurai Problematika Sosial, menyebutkan bahwa gerakan dari Civil Society pada dasarnya juga dapat memberikan kontribusi besar dalam upaya menjaga keharmonisan simpul sosial kemasyarakatan dalam upaya mecegah konflik ${ }^{7}$. Sebagai bagian dari kelompok Civil Society, maka peran pesantren dapat dikatakan menempati posisi strategis sebagai agen yang dapat memberikan pemahaman pada umat (masyarakat) akan perdamaian, sebagaimana konflik yang terjadi di Jabung. Hal ini dipertegas oleh riset yang dilakukan oleh Muqtafa bahwa Sebagai institusi keagamaan, pesantren memiliki peran yang sentral di tengah-tengah masyarakat. Sebagaimana tercatat dalam sejarah, komunitas pesantren terlibat aktif dalam prakarsa perdamaian mulai dari terlibat dalam menyelesaikan konflik komunal sampai merumuskan dasar kebangsaan Indonesia ${ }^{8}$.

Pondok pesantren Al-Ittihad di Jabung turut hadir dalam upaya penyelesaian konflik. Lambanya respon dari pemerintah atas seringnya terjadi konflik di masyarakat, maka Pondok Pesantren Al-Ittihad berinisiatif

${ }^{5}$ Pandu Alfredo, "Peran Polisi Dalam Mediasi Konflik Lahan Antara Warga Dengan Pt . Austasia Stockfeed Di Desa Negara Batin Kecamatan Jabung Kabupaten Lampung Timur", (Skripsi, Universitas Lampung, Bandar Lampung, 2019), 3.

${ }^{6}$ Moh. Hasim, "Karya Ulama Dalam Membangun Kedamaian Di Kalimantan Barat", Jurnal Al-Qalam, Vol.19. No. 1, (Juni 2013), 60.

7Thsan Hamid, "Urgensitas Masyarakat Madani Civil Society Dalam Mengurai Problematika Sosial: Suatu Tinjauan Terhadap Varian Konflik Di Lombok", Jurnal Kajian Sosial Keagamaan, Vol.02, No.01, ( Januari 2019), 46.

8 M.Khoirul Muqtafa, "Membincang Pesantren Sebagai Aktor Perdamaian Di Indonesia", Jurnal Masyarakat dan Budaya, Vol. 13, No. 2, (Desember 2011), 29. 
menggelar diskusi publik dengan tema "Peran Serta Masyarakat Dalam Penanganan dan Pemecahan Konflik Sosial" pada 31 Oktober 2016.

"Kegiatan diskusi memang pondok Al-Ittihad yang inisiatif, namun dalam pelaksanaanya kami bekerjasama dengan komunitas Himpunan Pemuda Jabung (HPJ) dan organisasi Gerakan Pemuda Ansor Jabung. Kegiatan diskusi publik ini menghadirkan dari unsur pemerintah dan tokoh masyarakat. Dengan adanya diskusi publik ini diharapkan pemerintah dapat merespon cepat jika terjadi perselisihan di masyarakat, terutama dalam menjaga keamanan" 9.

Dari kegiatan diskusi tersebut, dapat dipahami bahwa pondok pesantren terlibat aktif dalam penyelesaian masalah di masyarakat. Sehingga penjabaran masalah diatas, dapat dikatakan bahwa penelitian tentang strategi dan advokasi pesantren dalam menyelesaikan masalah publik penting untuk dilakukan. Hal ini bertujuan untuk mengetahui Bagaimanakah Strategi dan Advokasi Pondok Pesantren dalam menyelesaikan masalah konflik di masyarakat? Bagimana relasi Pondok pesantren dalam menyelesaikan masalah konflik di masyarakat, apakah melalui pemerintah atau terjun langsung ke masyarakat?

\section{LITERATUR RIVIEW}

Strategi dan advokasi dalam menyelesaikan masalah publik sudah sering dilakukan organisasi masyarakat sipil (OMS). Seperti riset Ardiyantika dengan tema Strategi Advokasi Perempuan Difabel Korban Kekerasan di SAPDA Malang. Dalam penelitianya dijelaskan bahwa strategi advokasi yang dilakukan SAPDA dapat dibedakan menjadi tiga jenis yaitu (1). Mikro, (2). Mezzo dan (3). Makro. Dalam implementasinya, strategi Mezzo merupakan strategi yang paling dominan digunakan oleh SAPDA hingga saat ini ${ }^{10}$.

Riset yang sama juga dilakukan oleh Wira Hospita, Aidil Zetra dan Afrizal mengenai Framing Gerakan Forum Masyarakat Minangkabau Dan Advokasi Kebijakan Investasi Di Kota Padang: Kasus Pt. Lippo Tbk. Hasil kajianya menjelaskan bahwa Gerakan Advokasi Kebijakan yang dilakukan oleh FMM terhadap kebijakan izin investasi PT. SPL dari Pemko berhasil mengubah (memodifikasi) regulasi mengenai perizinan investasi11. Gerakan FMM dapat diidentitaskan sebagai gerakan dari masyarakat Minangkabau dalam menolak bentuk penindasan dari kaum dominan dan otoritarian terhadap upaya merusak tatanan nilai-nilai yang telah didisposisikan oleh sistem sosial masyarakat Minangkabau.

9 Wawancara dengan Imdadul Munir (Sekertaris Pondok Pesantren Al-Ittihad, pada hari Kamis 10 Oktober 2019

10 Sulistyary Ardiyantika, "Strategi Advokasi Perempuan Difabel Korban Kekerasan di SAPDA", Jurnal Of Disability Studies, Vol.03, No. 02, (Juli 2016), 139.

11 Wira Hospita dkk, " Framing Gerakan Forum Masyarakat Minangkabau Dan Advokasi Kebijakan Investasi Di Kota Padang: Kasus Pt. Lippo Tbk", Jurnal KELOLA: Ilmu Sosial, Vol. 1, No. 1, ( Tahun 2018), 57. 
Sementara itu, Afriando melihat bahwa strategi advokasi adalah bagian dari advokasi itu sendiri. Menurutnya, keberhasilan dari advokasi merupakan ketepatan dalam menentukan strategi. Dalam risetnya menunjukkan bahwa Strategi advokasi yang digunakan SBMI Malang dalam melakukan advokasi kepada TKI Jawa Timur adalah strategi legal standing dan strategi negosiasi ${ }^{12}$.

Berbeda dengan kajian Basori dan Mukhlis, Fokus penelitianya lebih kepada melihat bagaimana cara menentukan model dan strategi dalam advokasi. Studi risetnya tentang Model Advokasi Organisasi Masyarakat Sipil Dalam Mendorong Kebijakan Distribusi Penguasaan Lahan Upaya Mewujudkan Masyarakat Yang Berkeadilan, menjelaskan bahwa Advokasi yang efektif atau mencapai hasil kebijakan yang diinginkan akan terjadi apabila OMS sebagai masyarakat sipil yang otonom dan kuat memiliki kemampuan kelembagaan permanen untuk :i) mengakses arena politik di mana kebijakan publik dan proses pengambilan keputusan berlangsung, ii) mengartikulasikan pers untuk sebuah perubahan kebijakan yang diinginkan, iii) memastikan bahwa setelah keputusan ditetapkan kemudian diimplementasikan, iv), memantau implementasi kebijakan, dan v), dan jika diperlukan mampu merumuskan perubahan kebijakan yang tidak lagi sesuai dengan kesepakatan dan tujuan awal penetapan kebijakan ${ }^{13}$.

\section{Konsep Strategi dan Advokasi}

Tema Advokasi lekat kaitanya dengan dunia hukum Menurut Bahasa Belanda, advocaat atau advocateur berarti pengacara atau pembela. Karenanya, tidak heran jika advokasi sering diartikan sebagai kegiatan pembelaan kasus atau beracara di pengadilan. Namun, penjelasan seperti itu tidaklah cukup, maka perlu dilakukan pelacakan yang cukup untuk mengetahui secara tuntas tentang konsep advokasi. Makna atau advokasi mempunyai arti yang luas, banyak pakar mempunyai pandangan mengenai advokasi yang berbedabeda.

Menurut Coullby advokasi merupakan an umbrella term' yang meliputi suatu metode, pendekatan, serangkaian alat yang digunakan untuk merubah kebijakan dan tindakan, mereformasi institusi, meribah sikap maupun prilaku $^{14}$

Dalam definisi lain Menurut Reid, advokasi digambarkan sebagai ekspresi tindakan individu dan kolektif. Menurutnya, advokasi dapat dipahami dengan mempertimbangkan aktifitas mempengaruhi opini publik, yang dapat meliputi pendidikan umum, menawarkan solusi yang lebih baik,

12 Andreas Afriando, "Strategi Advokasi Berjejaring Terhadap Tenaga Kerja Indonesia Oleh Serikat Buruh Migran Indonesia (Sbmi) Malang", Jurnal Ilmu Pemerintahan Universitas Brawijaya Malang, Vol. 13, No. , (Agustus 2014), 1-21.

${ }^{13}$ Yana Fajar FY. Basori, Maulana Mukhlis, "Model Advokasi Organisasi Masyarakat Sipil Dalam Mendorong Kebijakan Distribusi Penguasaan Lahan Upaya Mewujudkan Masyarakat Yang Berkeadilan", Jurnal FISIP Universitas Lampung, (Oktober 2017), 186.

$$
{ }^{14} \mathrm{Ibid}
$$


mobilisasi masyarakat, pengaturan agenda dan desain kebijakan, lobi, pelaksanaan kebijakan, pemantauan dan umpan balik, maupun keterlibatan dalam pemilu terkait dengan issue kebijakan tertentu ${ }^{15}$.

Dapat disimpulkan secara ringkas bahwa karakteristik dari advokasi adalah upaya atau proses untuk memperoleh komitmen yang dilakukan secara persuasif dengan menggunakan informasi yang akurat dan tepat. Advokasi yang dapat dilakukan individu maupun komunitas tersebut memiliki tujuan akhir untuk mengubah kebijakan atau mempengaruhi dan mengubah pemikiran masyarakat

Sementara itu, berkaitan dengan pelaksanaan advokasi, maka diperlukan sebuah strategi. Sebab kunci dari advokasi adalah strategi itu sendiri. strategi advokasi merupakan hasil dari proses dan riset advokasi yang memanfaaatkan seluruh data dan informasi yang diperoleh. Dengan mengolah data dan informasi serta menetapkan isu, membangun gerakan, dan mengumpulkan informasi yang dibutuhkan maka muncul strategistrategi advokasi yang berguna untuk menangani tiap masalah yang dialami ${ }^{16}$.

\section{Jenis-Jenis Atau Model Strategi Advokasi}

Keberhasilan dari advokasi bergantung dari pilihan strategi advokasi yang tepat. Menurut Hermawanto Strategi advokasi untuk melakukan perubahan bisa berupa hukum formal (litigasi) maupun upaya di luar hukum formal (nonlitigasi). Upaya hukum (litigasi) menggunakan mekanisme formal institusi hukum dan struktural administratif yanga ada, baik itu di kepolisian, kejaksaan, maupun peradilan. Sedangkan upaya di luar hukum, formal (non-litigasi memanfaatkan potensi kekuatan sosial dan politik yang tersedia, baik yang memiliki hubungan secara langsung maupun tidak lagsung terhadap advokasi yang dilakukan ${ }^{17}$.

Menurut Jane Covey dalam mengklasifikasikan strategi advokasi yang sering digunakan yaitu sebagai berikut:

1. Tabel1. Strategi Advokasi Kebijakan Jane Covey ${ }^{18}$

\begin{tabular}{|l|l|l|l|l|}
\hline \multicolumn{1}{|c|}{ Strategi } & \multicolumn{1}{|c|}{ Taktik } & Ketrampilan & Sumber Daya & \multicolumn{1}{|c|}{$\begin{array}{l}\text { Sifat-Sifat } \\
\text { Manusia }\end{array}$} \\
\hline $\begin{array}{l}\text { Pendidi- } \\
\text { kan }\end{array}$ & $\begin{array}{l}\text { Rapat-Rapat, } \\
\text { Media, } \\
\text { Lokakarya }\end{array}$ & $\begin{array}{l}\text { Riset, Aanalisis, } \\
\text { Penyebaran } \\
\text { informasi dan } \\
\text { komunikasi }\end{array}$ & $\begin{array}{l}\text { Alat tulis, } \\
\text { transport, } \\
\text { akomodasi, } \\
\text { peralatan } \\
\text { kantor dan }\end{array}$ & $\begin{array}{l}\text { Kesabaran, } \\
\text { kreatifitas, } \\
\text { presenter yang } \\
\text { baik }\end{array}$ \\
\hline
\end{tabular}

15 Ibid

16 Opcit.,

17 Monica Arlisa Kusuma Tiara, "Strategi Advokasi Komunitas People Like Us-Satu Hati Dalam Advokasi Hak Lgbt Di Yogyakarta", (Skripsi, Universitas Gadjah Mada, Yogyakarta, 2017), 32.

18 Ibid., 33 
STRATEGI DAN ADVOKASI PONDOK PESANTREN

DALAM MENYELESAIKAN MASALAH KONFLIK SOSIAL

\begin{tabular}{|l|l|l|l|l|}
\hline & & & bahan bahan & \\
\hline Kolaborasi & $\begin{array}{l}\text { Membangun } \\
\text { hubungan, } \\
\text { jembatan, } \\
\text { kerjasama } \\
\text { dengan } \\
\text { pemerintah }\end{array}$ & $\begin{array}{l}\text { Komunikasi, } \\
\text { mengorgani- } \\
\text { sasi }\end{array}$ & - & $\begin{array}{l}\text { Transparansi, } \\
\text { Keterbukaan, } \\
\text { kejujuran }\end{array}$ \\
\hline Persuasi & $\begin{array}{l}\text { Rapat, } \\
\text { Lokakarya, } \\
\text { koalisi, lobi, } \\
\text { Media, demo }\end{array}$ & $\begin{array}{l}\text { Mengorganisas, } \\
\text { komunikasi, } \\
\text { Motivasi, } \\
\text { berundin }\end{array}$ & $\begin{array}{l}\text { Peralatan } \\
\text { kantor, } \\
\text { akomodasi } \\
\text { transpot }\end{array}$ & $\begin{array}{l}\text { Kejelasan, } \\
\text { kreatifitas, visi, } \\
\text { kompromi, } \\
\text { keterlibatan }\end{array}$ \\
\hline Litigasi & $\begin{array}{l}\text { Menggunaka } \\
\text { n pengadilan }\end{array}$ & $\begin{array}{l}\text { Legislasi, } \\
\text { komunikasi } \\
\text { kengadilan, } \\
\text { praktisi } \\
\text { hukum }\end{array}$ & $\begin{array}{l}\text { Adil, jujur, tegas } \\
\text { dan jelas }\end{array}$ \\
\hline $\begin{array}{l}\text { Konfron- } \\
\text { tasi }\end{array}$ & $\begin{array}{l}\text { Demo, Rapat } \\
\text { umum, Orasi } \\
\text { dan pidato }\end{array}$ & $\begin{array}{l}\text { Memobilisasi, } \\
\text { komunikasi, } \\
\text { motivasi, } \\
\text { kepemimpinan }\end{array}$ & $\begin{array}{l}\text { Pemimpin- } \\
\text { pemimpin } \\
\text { modal, dan } \\
\text { pembicara } \\
\text { yang baik }\end{array}$ & $\begin{array}{l}\text { Keberanian, } \\
\text { pengorbanan, } \\
\text { kompromi, } \\
\text { keterlibatan }\end{array}$ \\
\hline
\end{tabular}

Sementara Mendoza memberikan gambaran yang hampir sama dengan strategi Jane Covey mengenai stratgei advokasi. Menurutnya, ada lima unsur utama yang harus dipertimbangkan dalam advokasi yaitu :

a) Tujuan jangka panjang, menengah dan jangka pendek.

b) Pertimbangan- pertimbangan organisasi.

c) Para pemilih, para sekutu, dan lawan.

d) Sasaran (yang dapat memberikan apa yang diinginkan)

e) Taktik. Uraian strategi utama ${ }^{19}$

Sedangkan Strategi Advokasi menurut, Flowers dan Goyal mengklasifikasikan strategi advokasi menjadi lima macam, yaitu²0:

1) Strategi Legal

Strategi legal dalam advokasi berkaitan dengan penciptaan sebuah aturan atau legal yang dapat mendorong sasaran advokasi untuk mengambil langkah sesuai dengan tujuan advokasi.

2) Strategi Riset

Riset adalah salah satu strategi yang dapat digunakan untuk mendorong sasaran advokasi agar memiliki empati dan komitmen terhadap hal yang diadvokasikan..

3) Strategi Politik

19 Democrito T. Mendoza, Kampanye dan Cara Melobi, (Jakarta: Yayasan Obor Indonesia, 2004), 29.

20 Flowers, Nancy dan Goyal, Rakhee, Mengembangkan Strategi Advokasi Yang Efektif, (Jakarta: Women 's Learning Partnership, 2003),34. 
Strategi politik juga perlu dilakukan untuk mengefektifkan advokasi yang dilakukan. Strategi ini berupaya untuk memetakan kekuatan dan menyatukan kepentingan agar bersinergi menuju apa yang dicita-citakan.

4) Strategi Negosiasi

Melakukan negosiasi penting dalam melakukan advokasi karena didalamnya terjadi proses komunikasi, sharing dan tawar menawar terhadap sasaran advokasi maupun pihak yang berkaitan dengan advokasi.

5) Strategi Media

Melalui media tertentu informasi, data, dan pendapat yang berguna bagi upaya advokasi dapat tersalurkan pada sasaran advokasi.

\section{Jenis-Jenis Atau Model Advokasi}

Dalam penerapan advokasi, banyak sekali teori atau model yang dapat dipakai dalam melakukan agenda advokasi. Misalnya menurut Sharma, ia mendevinisikan advokasi sebagai suatu tindakan individu, kolektif atau organisasi masyarakat yang terorganisir, sistematik berusaha untuk mempengaruhi pengambilan kebijakan agar lebih mempertimbangkan partisipasi masyarakat sipil dalam setiap kebijakan ${ }^{21}$.

Sebelum melakukan advokasi, perlu dipahami tahapan-tahapan yang harus dilakukan sebagai pedoman dalam melakukan advokasi itu sendiri. Dalam hal ini, Sharma menyebutkan 8 tahapan dalam advokasi, yaitu ${ }^{22}$ :

a) Memilih Tujuan Advokasi

Agar usaha advokasi manjadi berhasil, tujuan umumnya harus dipersempit sampai pada tujuan advokasi yang didasarkan pada jawaban terhadap pertanyaan-pertanyaan terkait

b) Menggunakan Data dan Penelitian untuk Advokasi

Data dan penelitian merupakan hal yang sangat penting untuk membuat keputusan yang tepat ketika memilih masalah yang akan ditangani, mengidentifikasi solusi bagi masalah tersebut, dan menentukan tujuan yang realistis.

c) Mengidentifikasikan Sasaran Advokasi

Jika masalah dan tujuannya telah dipilih, usaha advokasi itu harus diarahkan kepada orang-orang yang memiliki kewenangan untuk mengambil keputusan dan idealnya, kepada orang yang mempengaruhi pengambil keputusan itu

d) Mengembangkan dan Menyampaikan Pesan Advokasi

Berbagia macam sasaran advokasi memberikan tanggapan terhadap pesan yang berbeda-beda pula. Misalnya, seorang politikus mungkin tergerak hatinya kerika ia tahu berapa banyaknya orang di wilayahnya yang menaruh kepedulian terhadp probel tersebut.

e) Membentuk Koalisi

21 Sharma, Ritu R, Pengantar Advokasi: Panduan dan Latihan, (Jakarta: Yayasan Obor Indonesia, 2004), 23.

22 Ibid., 
Seringkali kekeuatan advokasi terdapat pada beberapa orang yang mendukung tujuan umum dari advokasi tersebut. Koalisi dan kerjasama berbagai pihak sangat diperlukan.

f) Membuat Presentasi yang Persuasif

Kesempatan untuk mempengaruhi sasaran advokasi yang merupakan tokoh kunci seringkali terbatas. Persiapan yang cermat dan mendalam untuk membuat argumen meyakinkan dan gaya penyajian mungkin dapat mengubah kesempatan yang sempit itu menjadi advokasi yang berhasil.

g) Mengumpulkan Dana untuk Advokasi

Sebagian besar kegiatan, termasuk advokasi, memerlukan sumber dana. Usaha untuk melakukan advokasi secara berkelanjutan dalam waktu yang panjang berarti mennyediakan waktu dan energi dalam mengumpulkan dana.

h) Mengevaluasi Usaha Advokasi

Untuk menjadi pelaksana advokasi yang efektif diperlukan umpan balik dan evaluasi terus-menerus mengenai usaha advokasi yang dilakukan

\section{POKOK MASALAH}

Konflik sosial yang terjadi di masyarakat Jabung Kabupaten Lampung Timur mengindikasikan bahwa lemahnya praktek keamanan di masyarakat. Sebagaimana tugas dan fungsinya dalam menjaga ketertiban di masyarakat, peran institusi pemerintah sangat dibutuhkan dalam situasi terjadi konflik di masyarakat. Pada sisi yang lain, Sebagai institusi keagamaan, pesantren memiliki peran yang sentral di tengah-tengah masyarakat. Sehingga dapat diartikan bahwa pondok pesantren sebagai bagian dari kelompok Civil Society dapat melakukan advokasi terhadap masalah konflik yang terjadi di masyarakat.

\section{TUJUAN PENULISAN}

Tujuan utama dalam tulisan ini adalah untuk mengetahui tentang strategi dan advokasi yang dilakukan oleh Pondok Pesantren Al-Ittihad dalam melakukan advokasi masalah konflik sosial di masyarakat.Tujuan lain dari paper ini adalah untuk menjelaskan bagaimana relasi pondok pesantren dalam menyelesaikan masalah publik, apakah melalui institusi Negara (Pemerintahan) atau justru langsung ke masyarakat.

\section{METODE PENELITIAN}

Dalam penelitian ini, metode yang digunakan adalah metode penelitian deskriptif kualitatif. Tujuan utama adalah mampu menggambarkan strategi advokasi yang digunakan oleh Pondok Pesantren Al-Ittihad Jabung Kabupaten Lampung Timur terhadap konflik sosial yang terjadi. Penelitian menggunakan teknik pengambilan data melalui wawancara dan dokumentasi. Proses analisis data dimulai dengan menelaah seluruh data yang tersedia dari berbagai sumber, yaitu dari wawancara, dokumen pribadi, foto, gambar dan sebagainya. Teknik analisis data yang 
digunakan yaitu pengumpulan data, persiapan data, tabulasi data, penerapan data dan kesimpulan

\section{PEMBAHASAN}

\section{Profil Pondok Pesantren}

Sejarah berdirinya Pondok Pesantren Al-Ittihad tergolong unik. Pada awal beririnya, Pondok pesantrean berada ditengah masyarakat yang abangan tidak tau agama. Pada awalnya, masjid dilingkungan pondok pesantren sebelum kedatangan Ky. Abas Sinwani yang selanjutnya menjadi pendiri pondok pesantren Al-Ittihad setiap pagi dipakai untuk main judi (Judi Klotok, istilah jawa). Dan ketika Ky. Abas Sinwani datang ke daerah, yaitu Desa Betengsari Kecamatan Jabung, Lampung Timur dipasrahi masyarakat sekitar untuk mengelola Masjid, karena diketahui sebagai lulusan pesantren.

Adapun sampai terjadi proses pendidikan pesantren diawali oleh Ibu Nyai Abas (Istilah istri kyai di pesantren) mengajarkan ngaji di Masjid. Masyarakat sekitar merespon positif dengan menyertakan anak-anaknya ikut mengaji. Semakin lama semakin banyak, sehingga pada tahun 1993 masyarakat sekitar membuatkan tempat pengajian dan menamainya AlIttihad. Adpun secara rinci, profil pondok pesantren Al-Ittihad adalah sebagai berikut :

a. Keadaan Yayasan

$\begin{array}{ll}\text { Nama Yayasan } & : \text { Al Ittihad } \\ \text { Alamat } & \text { :Jl. Pondok Pesantren Desa Benteng Sari, } \\ & \text { Kecamatan Jabung Kab. Lampung Timur } \\ \text { Pengasuh } & : \text { Ky. Abas Sinwani } \\ \text { Nama Ketua Yayasan } & : \text { Hj. Dewi Widianingsih } \\ & : \text { Muhammad Bahaudin (Ketua Harian) } \\ \text { Sekretaris } & : \text { Imdadul Munir } \\ \text { Bendahara } & \text { : Siti Mulyaningsih } \\ \text { Seksi Pendanaan } & : \text { Agus Khoirul Mukhlis, S.Pd.I } \\ \text { Seksi Humas } & \text { : Muhamad Qodi } \\ \text { Seksi Sarana dan Pras } & : \text { Imam Muslih } \\ \text { Seksi PHBI } & : \text { Imam Mujtahidin } \\ \text { Seksi Da'wah } & : \text { Masruri }\end{array}$

\section{b. Visi dan Misi}

Visi : Menjadikan TPA/TPQ Al-Ittihad yang memiliki kemampuan Intelektual tinggi serta nilai keimanan yang dapat dipertanggungjawabkan.

Misi : Mampu berkompeten, Demokrasi, Profesional, Transparan.

Tujuan : Mencetak lulusan yang berkwalitas, islami, Profesional, kompteten, dan berakhlakul kaeimah.

Strategi : Membina tenaga menuju Profesional kerja, Menciptakan suasana pendidikan yang efektif dan konduktif, Menjalin hubungan kemasyarakatan dengan baik, Mendidik, membina, mengembangkan dan memotivasi bakat santri. 


\section{c. Keadaan Pendidikan Yang ada di dalamnya}

1) Madrasah Diniyah

Nama diniyah

: Pon. Pes. Al-Ittihad

Alamat

: Jl. Pondok Pesantren Desa Benteng Sari,

Kecamatan Jabung Kab. Lampung Timur

Nama Kep. Diniyah : Ky. Abas Sinwani

Jumlah Tanaga Pend. : 6 Orang

\section{Bentuk Strategi dan Advokasi Pondok Pesantren}

Advokasi yang dilakukan oleh pondok pesantren adalah advokasi atas terjadinya konflik sosial di masyarakat. Konflik yang dimaksud adalah berkaitan dengan aksi kriminal yang kemudian dilakukan oleh sekelompok orang dalam hal ini kasus pencurian dan mengakibatkan polarisasi di masyarakat dan memicu terjadinya bentrok antar desa. Adalah konflik yang terjadi antara masyarakat desa Betengsari dan desa Negara Batin tahun 2016. Konflik tersebut bermula saat terjadi pembegalan kemudian pelaku tertangkap masa dan dihakimi sampai meninggal. Buntut dari kejadian itu, keluarga pelaku yang berasal dari Desa Negara Batin melakukan penuntutan kepada Desa Betengsari sebesar 200 juta. Ancamanya, bila tidak dipenuhi maka akan dilakukan penyerangan. Pasca dari peristiwa tersebut, konflik kembali terjadi di masyarakat. Penyebab utamanya juga berasal dari aksi kriminalitas. Masyarakat diresahkan dengan aksi pencurian. Kasusnya hampir sama dengan sebelumnya, jika pelaku tertangkap justru akan menancam dan melakukan perlawanan. Masyarakat yang awalnya diam, suatu ketika melakukan perlawanan dan munculah konflik yang semakin membesar.

Menyikapi atas kejadian tersebut, pondok pesantren Al-Ittihad bertindak melakukan mediasi dengan mengumpulkan beberapa tokoh masyarakat untuk melakukan musyawarah. Sebelumnya masyarakat sudah melakukan pengaduan ke pihak desa dan sudah ditangani oleh aparat kepolisian. Namun tindak lanjut atas penyelesaian masalah tidak dilakukan. Pada akhirnya masyarakat mengadu ke pondok pesantren Al-Ittihad agar dapat memberikan solusi permasalahan. Dalam konteks itulah pondok pesantren melakukan advokasi.

Langkah pertama yang dilakukan oleh pondok pesantren adalah mengumpulkan tokoh masyarakat dan tokoh agama untuk melakukan dialog. Pelaksanaan dialog dilakukan di balaidesa. Harapanya aparat pemerintah desa dapat memberikan keputusan dalam kaitanya menciptakan keamanan di masyarakat. Namun hasil dialog tidak ada kesepakatan. Bahkan kepala desa tidak menghadiri acara dialog tersebut. Dalam hal ini, tujuan advokasi yang dilakukan adalah mendorong pemerintah desa agar melakukan negosiasi perdamaian.

Pondok pesantren menilai bahwa terjadinya konflik di masyarakat karena aksi main hakim yang dilakukan oleh masyarakat itu sendiri. 
Sehingga menciptakan dendam bagi pihak korban (pelaku yang dihakimi masa).

Startegi pondok pesantren selanjutnya adalah berupaya mempertemukan pihak pihak yang berkonflik dalam sebuah dialog. Dengan melibatkan berbagi organisasi masyarakat, yaitu dari komunitas Himpunan Pemuda Jabung, Gerakan Pemuda Ansor Pondok Pesantren Al-Ittihad menggelar acara diskusi publik dengan tema "Peran Serta Masyarakat Dalam Penanganan dan Pemecahan Konflik Sosial". Kegiatan tersebut dihadiri oleh dari perwakilan pemerintah Kesbangpol Lampung Timur, Polres Lampung Timur dan Kodim Lampung Tengah. Dari unsur akademisi diwakili Dosen Universitas Nahdlatul Ulama. Hasil dari pertemuan tersebut adalah mengajak kepada seluruh masyarakat agar ketika terjadi aksi kriminal tidak melakukan penghakiman terhadap pelaku, tetapi agar diserahkan kepada pihak yang berwajib. Semua tokoh agama, tokoh masyarakat diharapkan agar memberikan edukasi kepada seluruh masyarakat supaya melarang melakukan aksi-aksi yang anarkis

Berikut adalah hasil wawancara yang dilakukan dengan salah satu pengurus pondok pesantren yaitu Imdadul Munir ${ }^{23}$

Pada tanggal 31 Oktober 2016, Pondok AL-Ittihad telah menggelar kegiatan dialog publik dengan tema "Peran Serta Masyarakat Dalam Penanganan dan Pemecahan Konflik Sosial" Apa benar ? Kapan dan Siapa saja yang terlibat dalam kegiatan itu?

“Benar..Untuk kegiatan dialog publik, pondok menginisiasi bersama komunitas HPJ (Himpunan Pemuda Jabung) dan Gp Ansor (Gerakan Pemuda Ansor) Jabung melakukan dialog bersama dengan mengundag tokoh-tokoh serta dari pihak pemerintah dan aparat keamanan. Kami gotong royong membentuk sebuah pertemuan besar diselenggarakan di halaman pondok. Kegiatan diskusi ini dilakukan pada tanggal 31 Oktober 2016.

\section{Mengapa pondok pesantren melakukan hal itu?}

"Kegiatan diskusi ini perlu kami lakukan karena bagaimana ya mas, karena respon pemerintah sangat lamban dalam menyikapi terjadinya konflik di masyarakat". Dan harapan masyarakat kan segera ingin selesai jika terjadi konflik-konflik begini. Maka ya kami berinisiatif mengundang tokoh masyarakat dan aparat pemerintah sekaligus bisa hadir di desa kami. Adapun tujuan pertemuan itu membahas mengenai penyelesaian konflik yang terjadi di masyarakat. Harapanya keamanan segera dapat pulih kembali.

Jika dilihat dari latar belakangnya, Sejak kapan konflik terjadi?

${ }^{23}$ Hasil dari wawancara dengan Sekertaris Pondok Pesantren Al-Ittihad, pada hari Kamis 10 Oktober 2019 
“Konflik terjadi sekitar pertenganhan tahun 2016. Ceritanya itu berawal ketika ada sekelompok orang yang membuat keributan. Dalam melakukan aksinya tertangkap oleh warga. Kemudian warga yang marah, melakukan penghakiman sampai meninggal dunia. Kawanan penjahat tidak terima dan menjadikan alasan tersebut untuk mencari uang. Alasan dari pihak pelaku adalah karena dirasa tidak manusiawi kok sampai dibakar. Dari kejadian tersebut, kelompok dari pihak pelaku tersebut menuntut ganti rugi 200 juta kepada pihak desa dan ketika tidak diberikan maka akan mengancam perang. Pada akhirnya masarakat desa Betengsari sendiri melakukan iuran 50 ribu100 ribu per kepala keluarga bahkan ada yang lebih, tujuanya untuk menebus tuntutan ganti rugi tersebut.

Dimana peran pemerintah dalam hal ini aparat keamanan menyikapi masalah ini?

"Jadi ceritanya begini. Suatu ketika aksi kriminal kembali terjadi. Ayam milik masyarakat sering dicuri. Pernah kejadian ada 2 orang berkendara motor ketahuan. Warga yang menegur, justru rumahnya diserang. Justru yang punya ayam tidak mau terlibat. Sebelumnya sudah, lapor ke polisi tidak ada respon. Harus ada bukti ada saksi. Kejadian sangat singkat maka sulit untuk membuktikan. Intinya sia sia ketika lapor ke polisi. Jarang penjahat yang ketangkep. Karena kejadian cepat sekali. Setelah lapor tidak ada tanggapan yang serius. Nah dari kejadian tersebut, masyarakat banyak mengadu ke pondok pesantren. Meminta agar dapat dibantu dalam menyelesaikan konflik yang terjadi".

Apa yang dilakukan pondok pesantren dalam menyikapi laporan masyarakat ketika menerima permintaan bantuan penyelesaian konflik?

"Merespon atas peristiwa tersebut, pondok pesantren berinisiatif mengadakan pertemuan bersama ketua RT dan tokoh masyarakat desa. Waktu itu ada kesalahan karena tidak ijin kepada pemerintah desa. Sehingga terkesan langkah yang dilakukan pondok disalahkan oleh pemerintah desa. Pada pertemuan selanjutnya, dilakukan secara formal di balaidesa. namun Kepala Desa tidak terlalu merespon dari keluhan masyarakat. Tujuan Pondok mengumpulkan tokoh masyarakat agar ketika terjadi keributan bagaimana caranya dibahas di balai desa bersama pejabat desa membahas masalah itu. Ada sekitar 20 orang hadir. Kebetulan pak lurah tidak hadir. Sehingga masyarakat kecewa karena tidak ada upaya penyelesaian. Maka kami berinisiatif mengajak tokoh masyarakat dan pemerintah agar duduk bersama membahas solusi terhadap konflik yang terjadi". Nah Alhamdulilah, setelah dialog dilakukan, pihak kepolisian menurunkan pasukan ke Jabung beberapa kompi untuk melakukan patroli. Seketika 
itu keamanan terwujud. Namun setelah selesai, aksi kriminal kembali terjadi.

Selanjutnya, Bagaimana strategi Pondok AL-Ittihad dalam mengupayakan penyelesaian konflik di masyarakat?

"Nah selanjutnya, untuk meredam suapaya konflik tidak kembali terjadi, pondok pesantren sendiri langsung memberikan edukasi kepada masyarakat. Salah satu kegiatan rutin yang dilakukan oleh pondok adalah, solawat (masbroan), Istighotsah setiap malam selasa. Satu bulan sekali Thoriqohan. Disetiap acara tersebut pondok memberi wawasan kepada masyarakat ketika terjadi konflik jangan anarkis. Lebih baik ditangkap dan diberikan ke pihak berwajib. Intinya jangan main hakim sendiri supaya tidak terjadi konflik. Masyarakat sudah mulai paham dan konflik sedikit tidak terjadi. "

Dari hasi wawancara tersebut, Jika dilihat dari model advokasinya, maka tahapan-tahapan advokasi yang dilakukan oleh pondok pesantren $\mathrm{Al}$ Ittihad dapat dilihat sebagai berikut:

a. Memilih tujuan advokasi

Tujuan dari advokasi yang dilakukan oleh pondok pesantren AL-Ittihad adalah menuntut upaya perdamaian. Dalam hal ini menuntut kepada pemerintah desa agar mendorong kasus ini ke pihak kepolisian.

b. Menggunakan Data dan Penelitian untuk Advokasi

Adapun data dalam penelitian ini adalah hasil kesaksian dari masyarakat yang disampaiakn ke pondok pesantren.

c. Mengidentifikasikan Sasaran Advokasi

Setelah tujuan dan data terkumpul, maka sasaran advokasi yang dilakukan pondok pesantren adalah pihak pemerintahan desa dan kepolisian.

d. Mengembangkan dan Menyampaikan Pesan Advokasi

Dalam melihat upaya penyampaian pesan advokasi, pondok pesantren menyampaikan pesan ini kepda seluruh tokoh masyarakat, pihak pemerintah desa dan kepolisian itu sendiri. Masyarakat diberikan pemahaman jika terjadi aksi kriminal agar jangan takut untuk melapor baik ke pemerintahan desa maupun kepolisian.

e. Membentuk Koalisi

Dalam membentuk koalisi, Pondok pesantren menjalin kerjasama dengan organisasi masyarakat sipil seperti HPJ (Himpunan Pemuda Jabung) dan GP Ansor Jabung.

f. Membuat Presentasi yang Persuasif

Dalam tahapan ini, data dan presentasi yang dimiliki sangat lemah. Pondok pesantren hanya memiliki kesaksian para korban di masyarakat tanpa ada bukti yang jelas, seperti Foto ataupun vidio rekaman.

g. Mengumpulkan Dana untuk Advokasi

Adapun dalam melakukan advokasi ini, dana diperoleh dari iuran masyarakat secara gotong royong. 
h. Mengevaluasi Usaha Advokasi

Usaha evaluasi sudah dilakukan, namun ketika mengetahui bahwa harapan dari tuntutan yang dilakukan tidak terpenuhi, seperti penanangaanan dari kepolisian yan kurang. Justru pondok pesantren mensikapi dengan memberikan edukasi langsung kepada masyarakat. Mengajak agar ketika terjadi tindakan kriminal, supaya bersabar dan cukup menangkap pelaku dan melaporkan ke pihak yang berwajib jangan dihakimi.

Selanjutnya, dalam melaksanakan advokasi tersebut, strategi yang dilakukan oleh pondok pesantren Al-Ittihad adalah strategi Persuasi dan Pendidikan. Sebagaimana Menurut Jane Covey mengklasifikasikan strategi advokasi yang sering digunakan yaitu; pendidikan, kolaborasi, persuasi, litigasi dan konfrontasi. Deskripsi strategi advokasi dijelaskan sebagai berikut:

\section{1) Strategi Persuasi}

Dalam pelaksanaanya unsur -unsur dari strategi persuasi adalah melakukan rapat, lokakarya, koalisi, lobi, Media, demo. Dalam hal ini, pondok pesantren Al-Ittihad menerapkan rapat dan musyawarah sebagai strategi untuk melakukan advokasi. Pada awalnya, pondok pesantren melakukan rapat dan dialog dengan menghadirkan tokoh agama, tokoh masyarakat, juga melibatkan dari unsur pemerintah yaitu Kesbangpol Lampung Timur, Polres Lampung Timur dan Kodim Lampung Tengah. Dari unsur akademisi diwakili Dosen Universitas Nahdlatul Ulama. Tujuan dari kegiatan ini adalah menggiring opini terhadap upaya penyelesaian konflik, terutama kepada kepolisian agar segera menindak aksi kriminalitas di Jabung secara tuntas.

Selanjutnya, koalisi yang dilakukan oleh pondok pesantren yaitu kepada organisasi masyarakat sipil seperti HPJ (Himpunan Pemuda Jabung) dan Gerakan Pemuda Ansor (GP Ansor) Jabung.

Kemudian, dalam kegiatan dialog tersebut, pondok pesantren juga melibatkan dari media-media lokal untuk melakukan peliputan dan penyebarluasan informasi. Tujuanya, agar mendapat perhatian yang serius dari pemerintah dan aparat kepolisian. Meskipun dalam strategi ini pondok pesantren tidak melakukan demonstrasi, namun cara-cara yang dilakukan adalah bagian dari strategi persuasi.

Dalam penerapan strategi ini dapat dikatakan berhasil. Ukuranya adalah sasaran advokasi yaitu aparat kepolisian terpengaruh dengan menerjunkan pasukan beberapa hari setelah dialog selesai. Patroli dilakukan di Jabung hampir selama 2 bulan. Keamanan mulai kondusif. Namun sayangnya, penyelesaian konflik bemum benar-benar tuntas. Pasalnya, setelah kegiatan patroli selesai, aksi kriminal kembali terjadi di masyarakat

2) Strategi Edukasi / Pendidikan

Dalam pelaksanaanya, strategi pendidikan ketrampilan yang dilakukan adalah Riset, analisis, penyebaran informasi dan 
komunikasi. Adapun taktik yang dipakai adalah rapat-rapat, media dan lokakarya. Strategi ini diterapkan oleh pondok pesantren Al-Ittihad sebagai solusi akhir dalam menyelesaikan konflik. Artinya, setelah dilakukan penindakan oleh aparat kepolisian pasca dilakukan dialog, aksi kriminalitas kembali terjadi. Munculnya konflik penyebab utamanya adalah kriminalitas. Masyarakat yang marah karena penjarahan yang dilakukan oleh sekelompok orang dari tetangga desa menimbulkan pertentangan di masyarakat.

Selanjutnya strategi pondok pesantren adalah memberikan edukasi dengan penyebaran informasi yang sifatnya mendidik masyarakat. Adapun pesan yang disampaikan adalah kesabaran dan larangan main hakim sendiri ketika menangkap pelaku kejahatan. Pesan edukasi tersebut disampaikan dalam acara rutinan yang diinisiasi oleh pondok pesantren seperti kegiatan rutin yang dilakukan adalah, Solawat Masbroan, Istighotsah setiap malam selasa. Satu bulan sekali Thoriqohan. Disetiap acara tersebut pondok memberi wawasan kepada masyarakat ketika terjadi konflik jangan anarkis. Lebih baik ditangkap dan diberikan ke pihak berwajib. Intinya jangan main hakim sendiri supaya tidak terjadi konflik.

\section{Analisis Relasi Strategi Dan Advokasi Pondok Pesantren Dalam Menyelesaikan Konflik}

Dalam melakukan advoksi konflik sosial di masyarakatt, Pondok Pesantren Al-Ittihad menerapkan strategi persuasi dan Pendidikan. Dalam penerapan strategi persuasi ini dapat dikatakan berhasil. Karena, aparat kepolisian yang menjadi sasaran advokasi terpengaruh dari isu yang dikembangkan. Aparat kepolisian melakukan penindakan dan patroli di Jabung dalam rangka menyelsaikan konflik. Seketika itu konflik tidak terjadi selama kurang lebih 2 bulan. Namun disayangkan ketika patroli tidak dilakukan, aksi kriminal kembali terjadi, dan peluang konflik kembali muncul di masyarakat.

Selanjutnya, untuk menyikapi keadaan tersebut pondok pesantren kembali melakukan advokasi dalam penyelesaian konflik yang terjadi. Strategi yang diambil adalah pendidikan atau edukasi. Aktifitas yang dilakukan adalah penyebaran informasi yang sifatnya mendidik masyarakat. Adapun pesan yang disampaikan adalah kesabaran dan larangan main hakim sendiri ketika menangkap pelaku kejahatan. Pesan edukasi tersebut disampaikan dalam acara rutinan yang diinisiasi oleh pondok pesantren seperti kegiatan rutin yang dilakukan adalah, masbroan, Istighotsah setiap malam selasa. Satu bulan sekali Thoriqohan.

Melihat strategi advokasi yang dilakukan oleh pondok pesantren AlIttihad tersebut, maka dapat ditarik garis besar bahwa relasi strategi dan advokasi pondok pesantren dalam menyelesaikan masalah publik lebih cenderung berhubungan langsung ke masyarakat. Hal itu dapat dilihat dari ciri-ciri sebagai berikut: 
a. Pondok Pesantren terlibat langsung dalam kegiatan mobilisasi masyarakat dalam penyelesaian konflik melalui kegiatan dialog publik yang di inisiasi oleh pondok pesantren

b. Upaya penyelesaian advokasi terhadap konflik sosial di masyarakat justru lebih efektif dengan cara edukasi melalui acara rutinan pengajian. kegiatan rutin yang dilakukan adalah, masbroan, Istighotsah setiap malam selasa. Satu bulan sekali Thoriqohan

c. Pondok pesantren melakukan kerjasama dengan komunitas di masyarakat seperti Gerakan Pemuda Ansor dan Himpunan Pemuda Jabung dalam membantu mengurai konflik di masyarakat. Dan strategi ini lebih dapat dikatakan berhasil dalam penyelesaian konflik di masyarakat.

\section{KESIMPULAN DAN SARAN \\ Kesimpulan}

Advokasi yang dilakukan oleh Pondok Pesantren Al-Ittihad di Jabung, Lampung Timur adalah berkaitan dengan adanya konflik sosial di masyarakat. Dalam implementasinya, pondok pesantren melakukan upaya dan strategi dalam membantu penyelesaian atas terjadinya konflik. Strategi yang dilakukan adalah strategi persuasi dan edukasi. Strategi persuasi dapat dilihat dari kegiatan dialog publik yang digagas oleh pondok AL-Ittihad dengan melibatkan pemerintah dan tokoh masyarakat. Adapun strategi edukasi dilakukan dengan menggelar kegiatan keagamaan dalam beberapa waktu seperti kegiatan solawat (Masbroan), Istigotsah dan thoriqoh an. Melalui kegiatan keagamaan tersebut, pondok Al-Ittihad memberikan pemahaman kepada masyarakat mengenai pentingnya hidup rukun dan damai dalam bermasyarakat. Selanjutnya, dapat dimaknai juga bahwa relasi pondok pesantren dalam upaya penyelesaian konflik lebih langsung terjun ke masyarakat dengan tidak melibatkan atau bekerjasama dengan pemerintah.

\section{Saran}

Saran dalam penelitian ini dapat diuraikan sebagai berikut

a. Strategi dan advokasi yang dilakukan oleh pondok pesantren Al-Ittihad kurang menekankan pada aspek evaluasi dan tindak lanjut. Sebab, tidak dilakukan upaya lain setelah tujuan dari advokasi tidak tercapai.

b. Strategi pendidikan memang efektif dalam memberikan edukasi ke masyarakat berkaitan dengan kesabaran dan patuh pada hukum. Namun tidak menjadi jaminan konflik tidak kembali terjadi, jika aksi kriminal masih sering terjadi di masyarakat. Maka sangat diperlukan peran pemerintah dalam menjaga keamanan. 


\section{DAFTAR PUSTAKA}

\section{Dari Buku}

Adi Suryadi Culla. 2019. Rekonstruksi Civil Society Wacana dan Aksi Ornop di Indonesia. Jakarta:LP3S

Democrito T. Mendoza. 2004. Kampanye dan Cara Melobi. Jakarta : Yayasan Obor Indonesia.

Flowers, Nancy dan Goyal, Rakhee. 2003. Mengembangkan Strategi Advokasi Yang Efektif. Jakarta: Women"s Learning Partnership

Sharma, Ritu R. 2004. Pengantar Advokasi: Panduan dan Latihan. Jakarta: Yayasan Obor Indonesia

\section{Dari Jurnal}

Afriando, Andreas. 2014. "Strategi Advokasi Berjenjang Terhadap Tenaga Kerja Indonesia Oleh Serikat Buruh Migran Indonesia (SBMI) Malang." FISIP Universitas Malang (13):1-21.

Ardiyantika, Sulistyary. 2016. "Strategi Advokasi Perempuan Difabel Korban Kekerasan Di SAPDA." Inklusi 3(2):193.

Basori, Yana Fajar FY. and Maulana Mukhlis. 2017. "Model Advokasi Organisasi Masyarakat Sipil Dalam Mendorong Kebijakam Distribusi Penguasaan Lahan Upaya Mewujudkan Masyarakat Yang Berkeadilan." (2011):186-99.

Hamid, Ihsan. 2019. “Urgensitas Masyarakat Madani Civil Society Dalam Mengurai Problematika Sosial: Suatu Tinjauan Terhadap Varian Konflik Di Lombok." SANGKéP: Jurnal Kajian Sosial Keagamaan 2(1):45-68

Husain, Moh. 2016. "Karya Ulama Dalam Membangun Kedamaian Di Kalimantan Barat." Al-Qalam 19(1):59.

Imadudin, Iim. 2009. "Konflik, Kekerasan, Dan Mediasi Sosial Di Pedesaan Lampung 1988-2001." Patanjala: Jurnal Penelitian Sejarah Dan Budaya $1(1): 1$

Pandu Alfredo. 2019. "Peran Polisi Dalam Mediasi Konflik Lahan Antara Warga Dengan PT.Austasia Stockfeed Di Desa Negara Batin Kecamatan Jabung Kabupaten Lampung Timur." Skripsi FISIP UNILA 53(9):01-84.

Silvana, Leydi. 2013. "Pemetaan Daerah Rawan Konflik Di Provinsi Lampung." Jurnal Bina Praja 05(03):169-76

Tiara, Monica Arlisa Kusuma. 2017. "Strategi Advokasi Komunitas People Like-Us Satu Hati Dalam Advokasi Hak LGBT Di Yogtakarta." Skripsi FISIP UGM 1-136.

Wira Hospita, Aidil Zetra, Afrizal. 2018. "ARTIKEL FRAMING GERAKAN FORUM MASYARAKAT MINANGKABAU DAN ADVOKASI KEBIJAKAN INVESTASI." Kelola Ilmu Sosial 1(1):57-69. 